\title{
Isolated renal echinococcosis: a rare disease
}

\author{
Madhusudan Patodia, Bhupendra Pal Singh, Satyanarayan Sankhwar, Siddharth Singh
}

Department of Urology, King George's Medical University, Lucknow, Uttar Pradesh, India

\section{Correspondence to} Dr Bhupendra Pal Singh bpsbhu@yahoo.com

Accepted 31 October 2015

CrossMark

To cite: Patodia $M$, Singh BP, Sankhwar $S$, et al. BMJ Case Rep Published online: [please include Day Month Year] doi:10.1136/ bcr-2015-213267

\section{DESCRIPTION}

Primary renal hydatid cyst is a rare disease. ${ }^{1}$ A 35-year-old woman presented with heaviness and a mass on the right side of her abdomen for 1 year. No history of loss of appetite, generalised weakness or weight loss was present. The medical history was unremarkable. On examination, a firm globular bimanually palpable mass was present in the right lumbar area extending from the right subcostal margin to the right iliac fossa. Ultrasonography revealed a right cystic renal mass (figure 1A). MRI detected an ill-defined heterogeneous cystic lesion
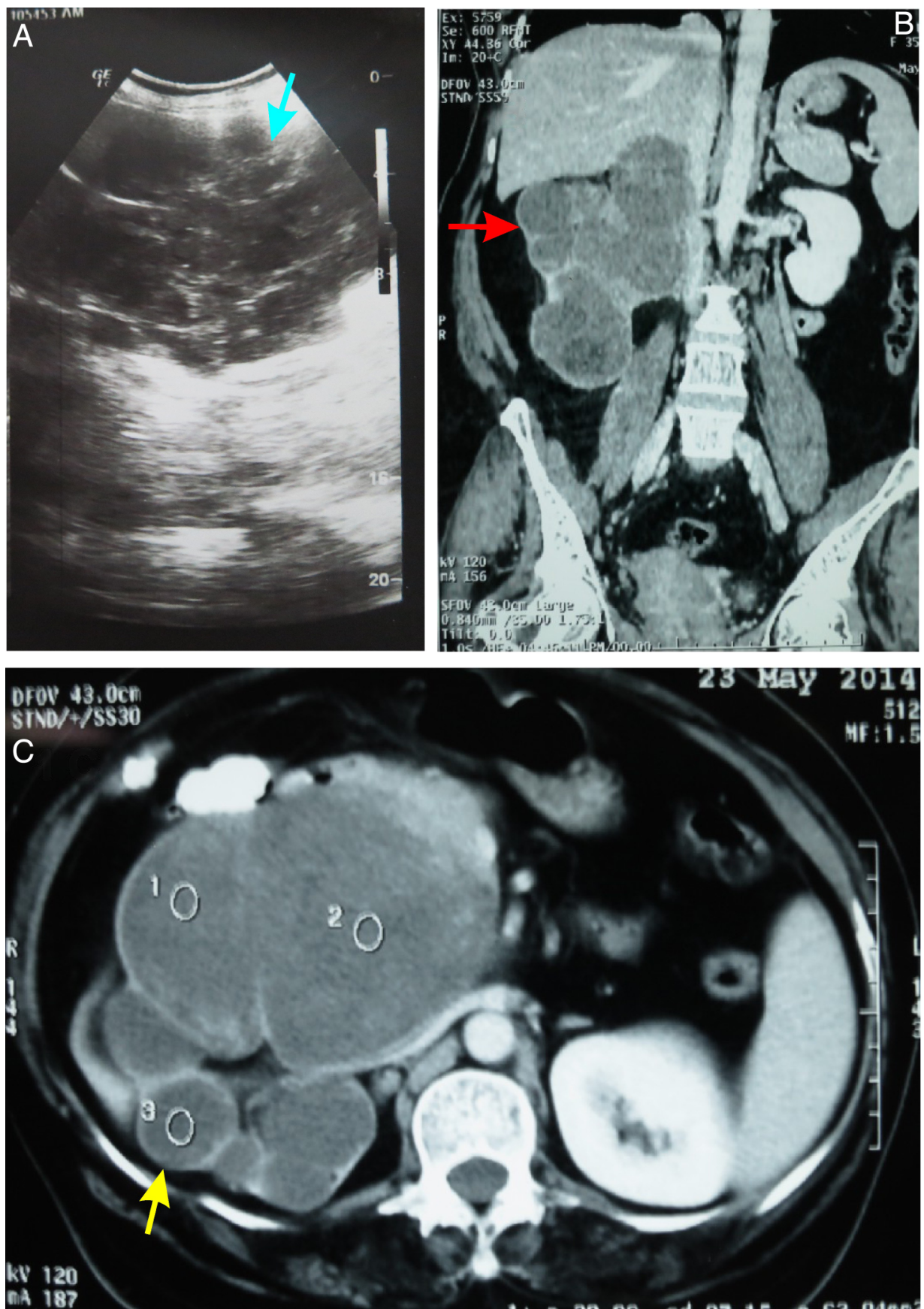

Figure 1 (A) Ultrasonography showing a right cystic renal mass (blue arrow). (B and C) MRI showing heterogeneous cystic lesion involving almost the whole of the right kidney (red arrow) and multiple small cystic areas (yellow arrow). 

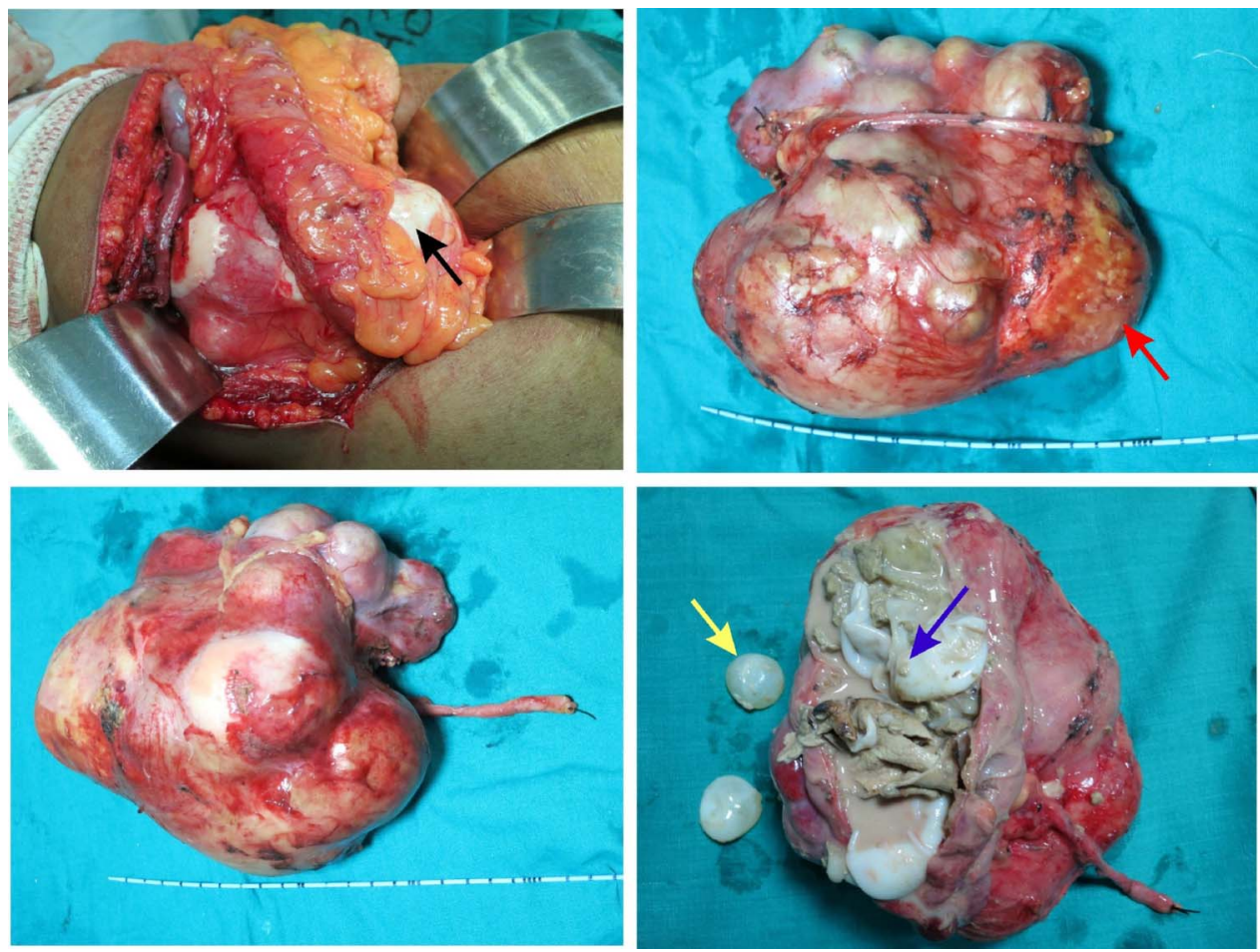

Figure 2 Intraoperative image showing calcified patches on the surface of the kidney (black arrow), whole kidney involved except for a rim of parenchyma at lower pole (orange arrow), smaller cysts (yellow arrow) having yellowish membrane filled with clear fluid and brood capsules (blue arrow).

\section{Learning points}

- Isolated hydatid disease of the kidney is a rare condition and may present as a large asymptomatic renal mass in an otherwise relatively healthy patient.

- Renal hydatid disease should be considered in the differential diagnosis for cystic lesions of the kidney, especially when treating people in or those migrating from endemic areas for echinococcosis.

- On imaging, a complex renal hydatid cyst may mimic cystic renal cell carcinoma.

- PAIR (puncture, aspiration, injection of scolicidal agent, re-aspiration) therapy, excision of the hydatid cyst, partial nephrectomy or total nephrectomy with peri-operative antihelminthic coverage are the appropriate treatment options according to the size of the cyst and the level of involvement of the kidney.

- Blind aspiration and spillage during the surgical procedure should be avoided.
$(15 \times 12 \times 10 \mathrm{~cm})$ involving almost the whole of the right kidney, with a few foci of calcification and multiple small cystic areas without any significant vascularity, suggestive of a renal complicated hydatid cyst (figure 1B, C). After starting oral Albendazole, abdominal exploration was carried out, which revealed a multilocular large renal cyst with calcified patches on the surface extending medially beyond the renal hilum (figure 2). Considering this extensive involvement of the kidney, a right nephrectomy was performed. Sectioning of the specimen revealed that the larger cysts were filled with calcified material, hydatid membranes and daughter cysts (figure 2). Histopathological examination revealed features of a hydatid cyst. Postoperatively, the oral Albendazole was continued. The patient was doing well 6 months after surgery.

Competing interests None declared.

Patient consent Obtained.

Provenance and peer review Not commissioned; externally peer reviewed.

\section{REFERENCE}

1 Shetty SD, AL-Saigh A, Ibrahim AIA, et al. Management of hydatid cysts of the urinary tract. Br J Urol 1992;70:258-61. 
Copyright 2015 BMJ Publishing Group. All rights reserved. For permission to reuse any of this content visit http://group.bmj.com/group/rights-licensing/permissions.

BMJ Case Report Fellows may re-use this article for personal use and teaching without any further permission.

Become a Fellow of BMJ Case Reports today and you can:

- Submit as many cases as you like

- Enjoy fast sympathetic peer review and rapid publication of accepted articles

- Access all the published articles

- Re-use any of the published material for personal use and teaching without further permission

For information on Institutional Fellowships contact consortiasales@bmjgroup.com

Visit casereports.bmj.com for more articles like this and to become a Fellow 